duction for these expenditures seems justified. The expense of meals, however, is rarely duplicated, and consistency at least would seem to justify deduction orily of the increment of expense over and above what the taxpayer would ordinarily pay for meals at his established residence. When the traveling taxpayer has no permanent residence, his deductions, if any, for both lodgings and meals should be limited to amounts in excess of what he would hypothetically pay at a permanent residence. The administrative difficulties of determining this increment hardly justify the discriminatory effect of a full deduction of living expenses in any of these situations. It is submitted that a sounder legislative solution would be to allow deduction of an arbitrary percentage of living expenses incurred while traveling on business. .54

\title{
ESTOPPEL, THIRD PARTY PRACTICE, AND INSURER'S DEFENSES
}

Liability insurance contracts commonly contain a provision obligating the insurer to "defend in the name and on behalf of the assured any claim or suit, whether groundless or not, covered by this policy and brought against the assured."I Valuable to the insurer as a protection against an indifferent defense or even a failure to defend on the part of the assured, this "defense" clause also benefits the assured by providing him with expert counsel. Difficulties arise when an injured party brings an action against the assured and subsequent investigation by the insurer reveals a breach of condition or an essential fact tend-

54 The drafters of the American Law Institute Tax statute apparently did not deem this matter sufficiently important to merit statutory modification. The pertinent section of the proposed statute provides: "Expenses of travel, including the entire cost of meals and lodging, in carrying on any gainful activity shall not be treated as personal, family, or living expenses. The term travel as used herein does not include ordinary transit of the taxpayer between his place of abode, permanent or temporary, and his nearest regular place of business." Federal Income Tax Statute $\$$ I5I (a)(I)(B)(ii) (tent. draft, I95I). The drafters give the following explanation for the proposed change: 'As to expenses of travel the terms 'away' and 'home' in section 23 (a) (I) (A) have been highly troublesome and are eliminated in this provision. The Bureau has taken the attitude that a taxpayer is not 'away' unless he stays at least

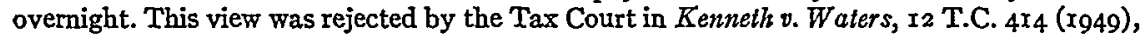
and no such requirement is adopted in this draft. Cases concerning the meaning of 'home' tend to make it mean 'principal place of business.' The suggested wording drops the term 'home' and adheres to the essential principle that an expense of travel, in order to be deductible, must be incurred in the pursuit of business. . . . In addition, the last sentence of subparagraph (ii), somewhat liberalizing present rules, specifically covers the troublesome situation where a taxpayer has more than one place of business. The decision of the majority of the Tax Court in Joseph $B$. Sherman ... is substantially in harmony with the proposed provision, although some suggestions of the case as to the characterization of 'home' are divergent." Ibid., at 208. The Model Code would evidently allow the taxpayer who spends ten months at a city in the pursuit of a business to deduct all his living expenses while living there even if he only spends two months at another place of business where he has an established residence. This result follows because the living expenses in New York are incurred "in carrying on ... gainful activity."

× See, e.g., Oehme v. Johnson, I8r Minn. I38, r40, 23r N.W. 817 (i930). 
ing to place the claim outside the coverage of the policy. Here the insurer's interest in restricting its obligation to the terms of the policy seems to conflict with its prospective duty as the assured's attorney. This conflict presents the insurer with an urgent strategical problem: whether or not to defend the assured.

It is well settled that assumption of the assured's defense constitutes a waiver by the insurer of all questions of policy coverage. ${ }^{2}$ If, therefore, in spite of its doubts as to coverage, the insurer elects to monopolize the defense of the assured, it will afterwards be estopped to deny its own liability under the policy. The "estoppel" referred to here is "estoppel by conduct"; it is ordinarily justified on the ground that the insurer has prejudiced the assured's right to control his own defense. Estoppel by conduct acts as a complete determination of the insurer's liability under the policy. ${ }^{3}$

With this in view, the insurer may wholly decline to assume the assured's defense when coverage is in doubt. Having refused to enter the litigation, the insurer cannot subsequently be estopped to set up in its own defense any matter not decided in the original action. ${ }^{4}$ Abstention presents a hazard, however, since the insurer will be "collaterally estopped" in the subsequent suit as to all issues which have in fact been decided in the prior action. ${ }^{5}$ And the danger of collateral estoppel is substantially increased where, in the insurer's absence, the assured and injured parties are free to collude for the purpose of establishing such facts as they may select in the light of the policy's coverage provisions. ${ }^{6}$ Finally, the non-liability of the assured is potentially the most effective bar to any policy claims against the insurer. Where any possibility exists of making a successful defense, the insurer has much to gain from placing its first reliance upon the innocence of the assured. In declining to defend, however, the insurer sacrifices all opportunity to contend against the injured party's claim.

Clearly, then, neither of the two primary alternatives is a satisfactory procedure for the insurer. The situation which emerges is, moreover, ethically unde-

2 American Casualty Co. v. Shely, ${ }_{234}$ S.W. 2 d 303 (Ky., I95o); Ashland Window \& Housecleaning Co. v. Metropolitan Casualty Co., 269 App. Div. 31, 53 N.Y.S. 2d 677 (I945); Jones v. Zurich General Accident \& Liability Ins. Co., I2x F. 2 d 76r (C.A. 2d, I94I); Klefbeck v. Dous, 302 Mass. 383 , I9 N.E. 2 d 308 (I939). For a discussion of Illinois law on this subject, see the dissenting opinion in De Hart v. Jllinois Casualty Co., Ir6 F. 2d 685 (C.A. 7th, I940).

3 American Casualty Co. v. Shely, ${ }^{234}$ S.W. $2 d 303$ (Ky., I950). The holding seems to be contra in Brown v. Kennedy, 49 N.E. 2d 4I7, 4I8 (Ohio, r942). The court there said, "The plaintiff claims the insurer is estopped to deny liability because the insurer defended the suit. ... The policy requires such defense, whether the action is valid or otherwise. Such action by the insurer does not constitute estoppel." Cf. London Guarantee \& Accident Co. v. Shafer, 35 F. Supp. 647 (S.D. Ohio, I940).

4 Miller v. United States Fidelity \& Casualty Co., 29r Mass. 445,449 , r97 N.E. 75,77 (I935); Potter v. Great American Indemnity Co., 316 Mass. I55, 55 N.E. $2 d$ I98 (I944); Rest., Judgments \& ro7 (1942).

5 Moulton v. Utica Mut. Ins. Co., I90 Misc. 878, 76 N.Y.S. 2d 34 (S.Ct., I948); Sanitary District of Chicago v. United States Fidelity \& Guaranty Co., 392 Ill. 602, 65 N.E. 2d 364 (r946); Saragan v. Bousquet, 322 Mass. 14, 75 N.E. 2 d 649 (r947); Stefus v. London \& Lancashire Indemnity Co., III N.J.L. 6, 166 Atl. 339 (r933).

${ }^{6}$ See cases cited note 7 infra. 
sirable, for it is noteworthy that accusations of bad faith, breach of fiduciary duty, and negligent defense are frequently found in these cases. ${ }^{7}$ The effect of the estoppel doctrines is to divide the loyalties of the insurer, to encourage concealment on the part of the assured, and to prompt the injured party dishonestly to distort his complaint when he fears that his adversary may prove impecunious. Such impropriety is the natural result of a situation overburdened with uncertainties. Uncertainty prevails not only as to the result of the original action and as to what issues of fact will be litigated therein, but also as to where the interests of the parties really lie. For the enlightenment of the parties, and to avoid the operation of the estoppel doctrines, the question of policy coverage should be answered prior to the conclusion of the original action. It is only a question of how.

Exclusive of legislation, ${ }^{8}$ three solutions have been attempted: non-waiver agreements, declaratory action, and third-party practice.

\section{I}

In the absence of any means by which to determine policy coverage before the liability of the assured is settled, the insurer may endeavor to suspend the operation of the estoppel doctrines with a non-waiver agreement. When coverage is in doubt, the insurer will offer to defend the assured under an agreement reserving to the insurer all of its policy defenses in case the assured is found liable. The courts have generally held such agreements valid.9

A concluded non-waiver agreement allows the insurer to retain control of the litigation, but does it enable the insurer to avoid the operation of the estoppel doctrines?

Estoppel by conduct operates as a result of the insurer's monopolization of the assured's defense. The assured, in reliance thereon, refrains from seeking other counsel. But no such reliance can be claimed where the insurer stipulates reservation of rights, since the assured can reject the insurer's offer of counsel

7 State Farm Mut. Automobile Ins. Co. v. Brooks, 43 F. Supp. 870 (W.D. Mo., I942) (insurer alleged collusion between assured and injured parties); Farm Bureau Mut. Automobile Ins. Co. v. Hammer, I77 F. 2d 793 (C.A. 4th, I949), noted in 4 Okla. L. Rev. I25 (1951); Carter v. Virginia Surety Co., 187 Tenn. 595, 2I6 S.W. 2d 324 (1948) (alleged violation of fiduciary relationship. by insurer); United States Fidelity \& Guaranty Co. v. Koch, IO2 F. 2d 288 (C.A. 3 d, r939) (inference of collusion between the injured party and the assured); Aetna Casualty Co. v. Quarles, 92 F. 2d 32 I (C.A. 4th, I937) (allegation of collusion between assured and injured parties); State Farm Mut. Auto Ins. Co. v. Bonacci, III F. 2d 4I2 (C.A. 8th, 1940) (allegation by insurer of collusion and negligent defense). The insurer "is at the mercy of every unscrupulous litigant who, regardless of his facts, sees fit to falsely allege a claim on which the insurance company would be liable ... and forsooth collect because the insurer cannot show the true facts. I cannot conceive this to be the law." Stefus v. London \& Lancashire Indemnity Co., I II N.J.L. 6, I I, I66 Atl. 339, 34I (I933) dissenting opinion.

${ }^{8}$ In two states, the injured party may bring his action directly against the insurer. Louisiana Stat. Ann. R.S. § 22: 655 (1950); Wisconsin Stat. § 260.1 (1947).

9 E.g., Shelby Mut. Casualty Co. v. Richmond, 185 F. 2 d 803 (C.A. 2 d, 1950); Salonen v. Paanenen, 320 Mass. 568, 7 I N.E. 2 d 227 (I947); Utilities Ins. Co. v. Montgomery, 134 Tex. 640,138 S.W. $2 d$ 1062 (r940). 
if he chooses..0 For this reason it is commonly held that an insurer defending under a non-waiver of rights agreement avoids the operation of estoppel by conduct and preserves its right to assert non-liability in a subsequent action on the policy. II

Whether in reserving rights the insurer also avoids the strictures of collateral estoppel is asyet unsettled..$^{\mathbf{2}}$ In contrast to estoppel by conduct, collateral estoppel arises as a result of the insurer's privity to the assured and is an "automatic" consequence of its position as indemnitor. ${ }^{{ }^{3}}$ Since the non-waiver agreement does not alter the fact of privity, it should not suspend the operation of collateral estoppel; and a defense should not afterwards be available to the insurer if such defense depends upon an issue of fact which has been determined adversely in the action between the assured and injured parties even though the insurer defended the action for the assured under a non-waiver agreement. If this reasoning is valid, the value of the non-waiver agreement is diminished, especially where the insurer plans to urge some central fact which, if proved, would place the injured party's claim outside the coverage of the policy. An adverse determination of such fact will bind the insurer in spite of the nonwaiver agreement. Nor is the active presence of the insurer always an effective safeguard against the adverse determination of a particular fact going to coverage, since the essential circumstance may be one which the insurer, as attorney for the defendant, cannot appropriately urge. This would be true if the assured had violated the law (as to speed limits, building codes, e.g.) to a degree which would excuse the insurer. ${ }^{14}$

It must also be remembered that the assured can accept or reject the nonwaiver agreement as he chooses, and that in rejecting, he is enabled to combine with the injured party to establish facts sufficient to bind the insurer under the policy. Even when the assured acts in good faith, the insurer's express and emi-

zo Hawkeye Casualty Co. v. Stoker, 154 Neb. 466, 48 N.W. 2d 623 (I95I); Great American Indemnity Co. v. Corpus Christi, I92 S.W. 2d 917 (Tex. Civ. App., I945).

II In most states the injured party is allowed to proceed directly against the insurer if his judgment against the assured has been returned unsatisfied. The insurer may make any defense against the injured party which would be available to it against the assured. E.g., Farm Bureau Mut. Automobile Ins. Co. v. Hammer, I77 F. 2d 793 (C.A. 4th, I949); Preferred Accident Ins. Co. v. Grasso, I86 F. 2d 987 (C.A. 2d, I95r); Schneider v. Autoist Mut. Ins. Co., 346 Ill. I37, I 78 N.E. 466 (I93I); Morgan v. Greater New York Taxpayers Mut. Ins. Ass'n, I04 N.Y.S. 2 d 876 (S. Ct., I95I). Contra: New Amsterdam Casualty Co. v. Jones, I35 F. 2 d I9I (C.A. 6th, 1943).

${ }^{2}$ See discussion in Shelby Mut. Casualty Co. v. Richmond, r85 F. 2 d 803, 805 (C.A. 2 d, 1950).

${ }^{13}$ See Scott, Collateral Estoppel by Judgment, 56 Harv. L. Rev. I (1942).

14 The clearest example appears where the assured has wilfully and intentionally inflicted injury, and policy coverage is limited to injuries "accidentally sustained." Miller v. United States Fidelity \& Casualty Co., 291 Mass. 445, 197 N.E. 75 (1935); New Amsterdam Casualty Co. v. Jones, I35 F. 2d I9I (C.A. 6th, I943); Stefus v. London \& Lancashire Indemnity Co., III N.J.L. 6, I66 Atl. 339 (I933). See McNeeley,Illegality as a Factor in Liability Insurance, 4 I Col. I. Rev. 26 (I94I). 
nently hostile declaration of non-liability may prompt such rejection. Representation of the assured by attorneys of its own selection is not uncommon in these cases. ${ }^{15}$

II

A second possible solution to the insurer's dilemma is the use of the declaratory judgment, ${ }^{16}$ a practice favored by insurers in recent years. ${ }^{37}$ The purpose of the declaratory judgment is to solve the issue of policy coverage with finality, and its significance to the present problem appears where the declaratory action is brought either prior to the commencement of suit by the injured party or while such suit is pending.

There is, however, some doubt as to the availability of declaratory relief. Several state courts have refused to allow declaratory actions under these circumstances on the ground that the insurer has an adequate remedy at law and can raise all defenses when sued later by the assured or injured party. ${ }^{18}$ Since Federal Rule of Civil Procedure 57 admits declaratory relief even when another remedy is available at law, the insurer may be able to bring its action in the federal courts. But where an action between the assured and injured parties is pending in a state court, problems arise regarding duplication of issues which again limit access to the declaratory action.

When the question of policy coverage depends upon an issue of fact relating to the injured party's claim rather than upon a breach of condition by the assured, the aim of the insurer in bringing a declaratory action is to avoid collateral estoppel by forcing a determination of that issue ahead of the conclusion of the state court suit. But when the vital issue of fact is likely to be litigated in the state court suit (which is precisely when the insurer has most to fear from collateral estoppel), the federal courts have commonly denied the insurer access to declaratory relief. $x 9$ Such relief will not be granted "for the purpose of trying issues involved in cases already pending ... or for the purpose of anticipating the trial of an issue in a court of co-ordinate jurisdiction."

Even if declaratory relief is granted on the grounds that the controversy between the parties will not necessarily be determined in the pending state court

15 See cases cited note to supra.

${ }^{6}$ Borchard, An Ohio Error, I7 Ohio St. Bar Ass'n Reports 507 (I945); Declaratory Judgments in Insurance Cases, 4 Okla. L. Rev. II8 (195I).

i7 See, e.g., Preferred Accident Ins. Co. v. Grasso, 186 F. 2d 987 (C.A. 2d, 195I). See annotation on this subject, $x_{42}$ A.L.R. 8 (I943).

${ }^{8}$ Utica Mut. Ins. Co. v. Beers Chevrolet Co., 250 App. Div. 348, 294 N.Y.S. 82 (I937); Wolverine Mut. Motor Ins. Co. v. Clark, 277 Mich. 633, 270 N.W. I67 (1936). Compare Dover Boiler Works v. New Jersey Manufacturers Gasualty Ins. Co., I8 N.J. Misc., 573, I5 A. $2 \mathrm{~d}$ 23I (S.Ct., 1950).

19 E.g., American Fidelity \& Casualty Co. v. Service Oil Co., I64 F. 2 d 478 (C.A. $4^{\text {th, }}$ I947); American Casualty Co. v. Howard, 80 F. Supp. 983 (W.D. S.C., I948).

${ }^{20}$ Aetna Casualty \& Ins. Co. v. Quarles, 92 F. 2d 32I, 324 (C.A. 4th, I937). 
action, ${ }^{2 r}$ there still remains the problem of predicting just what issues of fact will be litigated between the assured and injured parties. For this reason, the insurer may seek to enjoin the prosecution of the state court suit pending the outcome of the declaratory action. An injunction is especially necessary to the insurer where the assured is conducting an indifferent defense against the injured party and the state court suit seems likely to reach judgment at an early date..$^{22}$ Injunctions have been denied, however, in recent cases. ${ }^{23}$ It has been recognized that from the injured party's standpoint the delay caused by an injunction can be seriously damaging. Yet if the injunction does not issue, there may begin an "unseemly ... race for priority" :24 the first case decided would be res judicata on the other. ${ }^{25}$

Even assuming that declaratory relief is both feasible and desirable, certain disadvantages should be noted. Unless the insurer can assume the defense of the assured under a non-waiver agreement and at the same time bring a declaratory action against the assured-which makes the ethical tangle more hopeless than ever $^{26}$ - the assured must employ counsel to represent him in the original litigation as well as in the declaratory action. If the declaratory action is determined in favor of the assured or declaratory relief is denied while the original litigation is still in progress, replacement of the assured's counsel by the insurer's attorneys, coming at a late stage in the proceedings, could only impair the assured's defense. Having required the assured to employ other counsel by refusing to defend the suit in its beginnings, the insurer cannot insist upon replacement as of right. ${ }^{27}$ The effect, then, of resort to the declaratory action is an election by the insurer to relinquish control of the assured's defense in the original litigation. If declaratory relief is denied, the insurer stands in as vulnerable a position

${ }^{21}$ Central Surety \& Ins. Corp. v. Hampton, r79 F. 2d 26r (C.A. 5th, 1950); Associated Indemnity Corp. v. Davis, 45 F. Supp. $x 18$ (M.D. Pa., r942). See cases cited in Borchard, Declaratory Judgments 648 , note 53 et seq. (2d ed., I94I).

23 Despite the limitations of Section 265 of the Judicial Code, which provides that "the writ of injunction shall not be granted by any court of the United States to stay proceedings in any court of a State (except in bankruptcy cases)," an early line of decisions granted stays in such cases. See cases cited in Borchard, op. cit. supra note 21, at 66r n. 6.

${ }^{23}$ Glenn Falls Indemnity Co. v. Fredericksen, 8 F.R.D. 55, 6I-62 (D.C. Neb., 1947).

24 Borchard, op. cit. supra note 2I, at 663 .

${ }^{25}$ Carpenter v. Edmonson, 92 F. 2 d 895 (C.A. 5th, 1937).

${ }^{26}$ ' $H e r e$ not only did the insurer ultimately unequivocally deny liability on the policy but it instituted (declaratory) action wherein it repudiated liability, which action was instituted against the Stokers by the attorneys who were representing them in the damage cases.

"In the very nature of things, after this happened, could it be expected of the Stokers that they would further entrust the defense of their damage cases to attorneys employed by the insurer after the insurer caused such attorneys to take a position directly opposed to their interests?

"We think not, especially in view of the following paragraphs from the sixth section of the Canons of Professional Ethics....

" 'It is unprofessional to represent conflicting interests, except by express consent of all concerned. . .." "Hawkeye Casualty Co. v. Stoker, 154 Neb. 466, 48 N.W. 2d 623, 632 (I95I).

27 Tbid. 
as if it had wholly declined to defend or its offer of counsel under a non-waiver agreement had been rejected. Collateral estoppel doctrine would then apply with the dangers of collusion noted above.

Measured against the non-waiver agreement as a solution to the insurer's dilemma, the declaratory action is more serviceable in that it frequently enables the insurer to settle the question of policy coverage prior to the conclusion of the litigation between the assured and injured parties. ${ }^{28}$ Nevertheless, the insurer must face the possibility that declaratory relief will prove to be inaccessible. Also, by absenting itself from the original action from the outset when seeking declaratory relief, the insurer forever relinquishes its right to represent the assured in urging non-liability. Relinquishment of control of the litigation also increases the possibilities of collusion and indifferent defense. On the other hand, the non-waiver agreement (if accepted) allows the insurer to assume control of the assured's defense in an effort to prove the assured innocent and to avert an adverse determination of factual issues, and at the same time to avoid estoppel by conduct. But where declaratory relief is denied, or where the non-waiver agreement is rejected, the unprotected insurer must stand the risk of being collaterally estopped as to the factual issues in suit between the assured and injured parties.

It appears, then, that unless the courts exercise an unusually liberal discretion in granting declaratory relief and issuing injunctions against state proceedings, the benefit of the declaratory action is limited. Declaratory relief is presumably always available to the insurer in the federal courts where policy coverage depends upon an alleged breach of condition or upon some fact not likely to be litigated in the state court suit. However, since collateral estoppel would normally not prejudice the insurer's interest under these circumstances, the insurer might be content merely to deny liability and to remain inactive until suit is brought against it to enforce its obligations under the policy.

\section{III}

A third solution to the general problem, not yet widely attempted, is thirdparty practice. In Jordan v. Stephens v. Standard Accident Ins. Co., ${ }^{29}$ a contractor defending a negligence action was allowed under Federal Rule of Civil Procedure $I_{4}$ (a) to bring in his insurer as a third-party defendant after the insurer had declined to defend.

\footnotetext{
${ }^{28}$ E.g., Preferred Accident Ins, Co. v. Grasso, I86 F. 2 d 987 (C.A. 2d, I95I). "Not only is the company relieved by a judgment in its favor from defending a negligence action against the assured, but the determination of the fundamental economic fact that there is 'no coverage' enlightens and guides the injured person and the assured." Borchard, Declaratory Judgments 634-35 (2d ed., x $94 \mathrm{I}$ ). But where the insurer brings declaratory action prior to the commencement of litigation between the assured and injured parties, and joinder of the injured party is allowed, the injured party may defeat the insurer's attempt to determine the question of policy coverage separately from the issue of the assured's liability by filing a crossclaim for damages against the assured. The insurer is then placed in an anomalous position with regard to the assured, opposing him and at the same time faced with the possible duty to defend him. Merchants Indemnity Corp. v. Dana, 8 F.R.D. 32 (D.C. Conn., I948).
}

${ }^{29} 7$ F.R.D. I40 (W.D. Mo., I945). 
Impleader of the insurer can, of course, be accomplished only by the assured as defendant. ${ }^{30}$ To counterbalance this advantage, Federal Rule 24 , along with the sections in many state civil practice codes which provide for intervener, might be construed to allow the insurer to enter the proceedings on its own initiative in order to present its defenses without requiring subsequent litigation. ${ }^{3 x}$ Subsection (a) (2) of Federal Rule 24 gives to third parties an absolute right to intervene "when the representation of the applicant's interest by existing parties is or may be inadequate and the applicant is or may be bound by a judgment in the action." Regarding the first requirement, it is clear that the assured, insofar as he represents the insurer against the injured party, cannot be depended upon adequately to protect the insurer's interest under the policy. Indeed the reverse is more reasonably to be expected. ${ }^{32}$ And as to the second, it has been seen that an insurer "may be bound," through its privity to the assured, by the operation of collateral estoppel if issues going to policy coverage are litigated. In such cases the right of the insurer to intervene and contest the allegation should be absolute. Even where the injured party's complaint contains no allegations bearing directly on policy coverage, the interest of the insurer in the outcome of the litigation plus the ever-present possibility that it may be bound justifies the insurer's intervention.

Under the broad rule of intervention adopted in more than one-half of the states, an insurer should be allowed to enter in its own interest even with defenses which are entirely new or foreign to the main cause. "An intervention takes place when a third person is permitted to become a party to an action or proceeding between other persons... by demanding anything adversely to both the plaintiff and the defendant." 33 If the word "both" is emphasized in objection to the insurer's intervention, it may be answered that in those states where the injured party is allowed to proceed by way of garnishment or otherwise against the insurer after his judgment has been returned unsatisfied, a

${ }^{30}$ Diversity requirements sometimes raise difficulties in the federal courts. Before the amendment of Rule 14 (see note 34 infra), the defendant was permitted to implead a third party "who is or may be liable to the plaintiff for all or part of the plaintiff's claim." Requisite jurisdiction was held to be lacking where the plaintiff and the third-party defendant enjoyed common citizenship. As amended, the Rule provides that the defendant can implead a third party only when the latter is or may be liable over to the defendant for all or part of the plaintiff's claim. The jurisdictional requirement is thus narrowed to diversity between the defendant and third party. See Federal Jurisdiction, 22 Tulane L. Rev. 328 (I947).

$3 x$ "Intervention counterbalances the many devices of joinder. Its utility lies in offering protection to non-parties, who obviously comprise a large and undefined group with varied interests, oftentimes of tremendous financial and legal importance." 4 Moore, Federal Practice 6 (2d ed., I948). On this subject generally, see Moore and Levi, Federal Intervention, 45 Yale L.J. 565 (I936).

${ }^{32}$ Inadequate representation is sufficient ground for intervention by a surety. United States v. American Surety Co., I42 F. 2d 726 (C.A. 2d, I944). See Price v. Carlton, I21 Ga. I2, 48 S.E. 72 ( $\left(\mathrm{I}^{\circ} \mathrm{O}\right)$. The position of a surety when suit is brought against its principal seems precisely that of an insurer when its assured is named defendant in an action for damages. Neither insurer nor surety is likely to receive adequate representation and both stand to be bound by a judgment rendered against the assured or the principal.

${ }^{33}$ Clark, Code Pleading 42 I n. 284 (2d ed., I94r). 
challenge as to policy coverage is distinctly adverse to the injured party's interest as well as to the assured. Practically, the question of policy coverage is often of greater importance to the injured party than to the assured.

It is important to inquire, however, whether the use of third-party practice will obviate the operation of the estoppel doctrines. ${ }^{34}$ Estoppel by conduct and collateral estoppel arise in favor of the assured or injured party, if at all, upon the advent of a second suit, i.e., between the assured or injured party and the insurer. Conversely, third-party practice is predicated upon unity of action. It is true that where an insurer has intervened or been impleaded, its policy defenses and the plaintiff's complaint may not, under all circumstances, be capable of presentation to a jury at one and the same moment. The insurer's policy defenses may be prejudicial to the assured's defense; 35 the court may wish temporarily to conceal the fact that the defendant is insured; ${ }^{36}$ or it may be that simultaneous litigation of the insurer's defenses and the plaintiff's claim will unduly complicate the proceedings. ${ }^{37}$ Here, as a matter of convenience, the court may delay an adjudication of the insurer's policy defenses until after, or require such adjudication before, a determination of the assured's liability. But even then the litigation is a whole, not a fractured, action. In this state of things the doctrine of collateral estoppel (res judicata) has no significance or application. Clearly, no question of estoppel by conduct (prejudice) can arise, since the insurer has sufficiently expressed its disclaimer of liability in declining to defend the assured and in entering the litigation as a third party.

Where policy coverage is in doubt, it has been seen that in the absence of third-party procedure the insurer must institute a declaratory action in order to preserve its defenses under the policy, or, in the alternative, offer a nonwaiver agreement in order to preserve its capacity to represent the assured. But where the insurer enters the litigation as a third party, it may present both its own and the assured's defenses within the framework of the single action. To a great extent this negatives the possibility of collusion between the assured and injured parties.

From the standpoint of the assured, third-party practice is likewise of great advantage. Impleader enables the assured to sue the insurer on the policy with-

${ }^{34}$ Prior to the amendment of Federal Rule $\mathrm{I}_{4}$, a third-party defendant was "bound by the adjudication of the third-party plaintiff's liability to the plaintiff." This sentence has been omitted in the amended Rule, and in theory as well as practice it seems unlikely that a third party, having intervened or been impleaded into the proceedings, can be bound by a judgment rendered solely on the plaintiff's complaint. 3 Moore, Federal Practice 432 (2d ed., I948); Willis, Five Years of Federal Third Party Practice, 29 Va. L. Rev. 98x (I943).

35 Farm Bureau Mut. Automobile Ins. Co. v. Hammer, I77 F. 2d 793 (C.A. 4th, I949); Stefus v. London \& Lancashire Indemnity Co., ir I N.J.L. 6, x66 Atl. 339 (x933).

${ }^{36}$ Pecor v. Home Indemnity Co., 234 Wis. 407, 29 I N.W. 313 (r940).

37 Brune v. MacDonald (Pacific Indemnity Co., Intervenor) I58 Ore. 364,75 P. $2 d$ Io (1938). The action arose out of injuries sustained in an auto accident. Defendant's insurer sought to intervene, alleging collusion and praying that the policy be declared void. The court denied the petition for intervention on the ground that it introduced new and complicating issues into litigation. Query whether this reasoning does not defeat the primary purpose of the intervener statute, i.e., to prevent a multiplicity of suits. 
out costly delay and before the insurer has had opportunity to bring a declaratory action. At the same time, the assured, if defending in good faith, should have no objection to intervention by an insurance company which can employ its skill and experience in the assured's behalf without fear of estoppel by conduct.

From the injured party's point of view, the presence of the insurer as a third party eliminates the necessity of a secondary action against the insurer as subrogee of the assured, in which the burden of proof would be on him, not on the insurer, to show that assured was covered by the policy..$^{38}$ In addition, the injured party will receive first-hand information on the insurer's policy defenses and will have an opportunity to decide on the basis of full knowledge whether an early settlement is not the more prudent course of action.

Perhaps the only meaningful disadvantage of third-party practice to the insurer is the possibility of jury prejudice. Since the insurer is a party litigant, its identity can hardly be concealed from the jury. Recent opinion tends to deemphasize the importance of this factor, however. Contemporary juries are inclined to assume that defendants carry insurance as a matter of course. In addition, opposing counsel are generally able to inform the jury of the existence of insurance, so that jury prejudice is not likely to be much greater when the insurer is an admitted party than when it appears "anonymously" as attorney for the assured. 39

A second factor sometimes thought to militate against the use of third-party procedure is the "no-action" clause. Standard liability forms contain a provision stipulating that "no action shall lie against the company ... until the amount of the assured's obligation to pay shall have finally been determined by judgment." ${ }^{\circ}$ The purpose of the "no-action" clause is patently to protect the insurer against hostile jury sentiment. But in line with a more realistic conception of the diminishing importance of the jury "secret," $4 \mathrm{x}$ at least one court has held the "no-action" clause ineffective as a bar to third-party procedure.42

${ }^{38}$ Preferred Accident Ins. Co. v. Grasso, I86 F. 2d 987 (C.A. 2d, I95I); Travelers Ins. Co. v. Greenough, 88 N.H. 39I, I9o Atl. I29 (r927).

39 Disclosure of Insurer's Interest in Voir Dire Examination of Jurors in Illinois, $43 \mathrm{Ill}$. L. Rev. 650 (r948).

40 Appleman, Joinder of Policyholders and Insurers as Parties Defendant, 22 Marq. L. Rev. 75 (I938). Damiano v. Damiano, 6 N.J. Misc. 849, I43 Atl. 3 (S. Ct., I928).

42 Pre-trial examination of defendants as to the existence and the provisions of any liability insurance carried by defendants is now permitted in the federal courts. Brackett v. Woodall Food Products, I2 F.R.D. 4 (E.D. Tenn., I95I); Orgel v. McCurdy, 8 F.R.D. 585 (S.D. N.Y., I948).

42 Jordan v. Stephens v. Standard Accident Ins. Co., 7 F.R.D. I40 (W.D. Mo., I945). The "no-action" clause has been held a bar to joinder of the insurer as co-defendant. Crowley v. Hardman Bros., I 22 Colo. 489, 223 P. 2 d I045 (I950). There is, of course, an essential difference between a co-defendant and a third-party defendant. Where the insurer is co-defendant its primary defense must be made against the allegations of the injured party as to the conduct of the assured. Where the insurer is third-party defendant it need reply only to the assured on the issue of policy coverage and is not bound by a determination of the assured's liability to the plaintiff. See note 34 supra. 
In summary, third-party practice, when compared with the declaratory action as an approach to the insurer's problem, presents this advantage: it enables the insurer to litigate issues of fact going to coverage without requiring the insurer to absent itself from the action between the assured and injured parties. Compared with the non-waiver agreement, it is clear that third-party practice, in enabling the insurer to present defenses on behalf of the assured as well as to urge its own non-liability under the policy, eliminates both the possibility of rejection of counsel by the assured and the necessity of a second suit to determine the insurer's liability under the policy. Finally, third-party practice moots all question of estoppel. Presumption of jury prejudice, however, and the recognition heretofore accorded the "no-action" clause, are obstacles, to a wider use of the third-party solution. ${ }^{43}$

\section{COMPETITION AND TV PROGRAM CONTENT}

"One of the more important sources of the retardation or regression of civilization is man's tendency to use new inventions indiscriminately or too hurriedly without adequate reflection of long-range consequences."

Frankfurter, J., dubitante.*

\section{I}

However anomalous, one of the most significant facts in the on-rush of video has been the absence of a systematic legislative attempt to cope with its problems. Because of the more or less chance presence of a clause in the Communications Act giving the Commission jurisdiction over the transmission of images ${ }^{\mathrm{x}}$ and because the organizations concerned with both the programming and technical phases of TV have to a very large extent been those which have dominated radio, lethargy has thus far won out, and TV has been permitted to trip and stumble along the road originally charted out for its older brother. ${ }^{2}$

The wisdom of such a course is dubious. The decisions of the Commission in

43 Jacobs v. Pellegrino, 154 Misc. 651, 277 N.Y. Supp. 654 (S. Ct., 1935).

* Radio Corp. of America v. United States, 34I U.S. 4I2, 425 (I95I).

${ }^{2} 8$ Stat. I06 $_{5}$ (1934), 47 U.S.C.A. \$ I53(b) (Supp., r95 I).

2 The consequences of not paying rigid attention to the early developments in radio were catastrophic. Siepmann, Radio's Second Chance I-I4 (I946); White, The American Radio II et seq., I 28-30 (I947). Not only was there absent a well-planned method of finance (the first extensive broadcasting was carried on by the set manufacturers as a means of increasing their revenues), but no agency was provided for resolving the technical problems of interference. The first federal regulation of radio, the Radio Act of I9I2, 37 Stat. 302 (IgI2), concerned with radio telegraphy, provided for the licensing of broadcasters by the Secretary of Commerce, but was held insufficient to authorize licensing designed to end interference. Hoover v. Intercity Radio Co., 286 Fed. 1003 (App. D.C., I923); United States v. Zenith Radio Corp., I2 F. 2 d 6r4 (D.C. Ill., I926). The latter decision was followed by the Radio Act of 1927,44

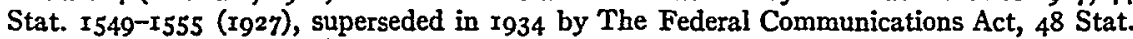
I064 (r934), 47 U.S.C.A. § I5I et seq. (Supp., I95I). 